\title{
IDENTIFIKASI KEMAMPUAN BERPIKIR KRITIS SISWA SMA PADA POKOK BAHASAN OPERASI BENTUK AKAR BERDASARKAN GENDER
}

\author{
Siti Masruroh', Eko Listiwikono², Barep Yohanes ${ }^{3}$ \\ Universitas PGRI Banyuwangi \\ Email : Masruroh.mas27@gmail.com
}

\begin{abstract}
Abstrak
Kemampuan berpikir kritis pada mata pelajaran matematika sangat penting, tidak hanya untuk mencapai tujuan umum pembelajaran matematika, tetapi juga untuk menciptakan manusia berkualitas yang mampu menciptakan dan menguasai teknologi dimasa depan. Indikator dari berpikir kritis adalah: focus (fokus); reason (alasan); inference (menyimpulkan); situation (situasi); clarity (kejelasan); dan overview (tinjauan ulang).

Penelitian ini berjenis deskriptif kualitatif yang bertujuan untuk menganalisis dan mengidentifikasi kemampuan berpikir kritis siswa dalam menyelesaikan soal operasi bentuk akar. Responden penelitian adalah 17 siswa di SMA Muhammadiyah 4 Songgon kelas X IPA 2. Selanjutnya ditentukan subyek masing-masing 3 berdasarkan gender. Pengumpulan data dilakukan dengan metode tes, wawancara, dan dokumentasi. Wawancara berfungsi sebagai triangulasi data.

Hasil penelitian menunjukkan bahwa siswa perempuan cenderung lebih kritis khususnya dalam memecahkan masalah soal operasi bentuk akar. Siswa perempuan juga lebih benar dan teliti dalam menyelesaikan soal tes. Sedangkan siswa laki-laki benar dalam menyelesaikan soal, namun kurang teliti dalam menyelesaikan soal tes. Akibatnya ada tahapan pengerjaan soal yang terlewatkan.
\end{abstract}

Kata Kunci: Berpikir kritis, Operasi Bentuk Akar, Gender

\section{PENDAHULUAN}

Pendidikan merupakan hal yang sangat penting dalam kehidupan manusia, hal ini berarti bahwa setiap manusia berhak mendapatkannya dan diharapkan untuk selalu berkembang didalamnya. Menurut Kafiar \& Kho (2015:40) bahwa pendidikan merupakan ujung tombak perkembangan suatu negara. Pendidikan yang berkualitas pada suatu negara dapat mencetak generasi penerus bangsa yang berkualitas dan berkompetensi untuk membangun negara tersebut menjadi negara yang lebih maju. Pendidikan merupakan faktor utama dalam pembentukan pribadi manusia. Pendidikan bisa didapatkan dimana saja, mulai dari lingkungan keluarga, masyarakat, maupun lingkungan sekolah. Pendidikan mempunyai peranan penting dalam kelangsungan perkembangan kemajuan suatu negara. Melalui pendidikan 
kehidupan manusia akan terarah. Pendidikan merupakan sarana untuk meningkatkan dan mengembangkan kualitas sumber daya manusia dalam berpikir.

Berpikir merupakan aktivitas mental untuk mengambil keputusan dalam menyelesaikan masalah. Mulai dari aktivitas merumuskan masalah hingga menyelesaikan masalah, seseorang akan melakukan aktivitas berfikir. Berfikir merupakan suatu kegiatan mental yang dialami seseorang bila mereka dihadapkan pada suatu masalah atau situasi yang harus dipecahkan (Sagala, 2011:2). Proses berpikir seseorang terdapat proses tingkat tinggi. Seseorang harus menggunakan otak kanan dan otak kiri secara seimbang agar dapat melakukan proses berpikir tingkat tinggi. Proses berpikir tingkat tinggi dibagi menjadi 2 yaitu berpikir kreatif dan berpikir kritis.

Kemampuan berpikir kritis pada mata pelajaran matematika sangat penting, tidak hanya untuk mencapai tujuan umum pembelajaran matematika, tetapi juga untuk menciptakan manusia berkualitas yang mampu menciptakan dan menguasai teknologi dimasa depan. Matematika merupakan salah satu mata pelajaran pokok yang ada sejak pendidikan dasar dan dapat membentuk pola pemikiran yang logis, sistematis maupun kritis. Matematika merupakan salah satu mata pelajaran yang diajarkan pada setiap jenjang pendidikan (Julita, 2018:144).

Salah satu materi matematika yang diajarkan di SMA/MA adalah Operasi bentuk akar. Kebanyakan siswa SMA/MA yang merasa kesulitan untuk dapat memahami permasalahan-permasalahan yang diberikan oleh guru yaitu menghitung dalam bentuk akar. Kesulitan siswa dalam mempelajari materi ini terjadi karena kurang memahami perubahan bentuk pangkat ke bentuk akar. Siswa juga kurang teliti dalam mengerjakan operasi bentuk akar dalam penyelesaian soal.

Berdasarkan latar belakang yang telah diuraikan, maka dapat ditentukan rumusan masalah dalam penelitian ini adalah bagaimana kemampuan berpikir kritis siswa kelas X IPA 2 pada pokok bahasan operasi bentuk akar berdasarkan gender. Sehingga tujuan dari penelitian ini adalah mendeskripsikan kemampuan berpikir kritis siswa kelas kelas X IPA 2 pada pokok bahasan operasi bentuk akar berdasarkan gender. 
Berpikir kritis merupakan proses berpikir yang kompleks yaitu berpikir secara matematik dan berpikir kreatif, dengan tujuan untuk membuat keputusankeputusan yang masuk akal yang meliputi kegiatan menganalisis, mensintesis, mengenal permasalahan dan pemecahannya, menyimpulkan serta mengevaluasi. Menurut Ennis (2009) dalam berpikir kritis terdapat enam indikator yaitu Focus (fokus), Reason (alasan), Inference (menyimpulkan), Situasion (situasi), Clarity (kejelasan), dan Overview (tinjauan ulang). Penjelasannya menurut Sulianto (2012:36-37) yaitu:

a. Focus (fokus)

Langkah awal dari berpikir kritis adalah mengidentifikasi masalah dengan baik. Permasalahan yang menjadi fokus bisa terdapat dalam kesimpulan sebuah argumen.

b. Reason (alasan)

Apakah alasan-alasan yang diberikan logis atau tidak untuk disimpulkan seperti yang tercantum dalam fokus.

c. Inference (simpulan)

Jika alasannya tepat, apakah alasan itu cukup untuk sampai pada kesimpulan yang diberikan?

d. Situation (situasi)

Mencocokkan dengan situasi yang sebenarnya.

e. Clarity (kejelasan)

Harus ada kejelasan sehingga tidak terjadi kesalahan dalam membuat kesimpulan.

f. Overview (tinjauan ulang)

Artinya mengecek kembali apa yang sudah ditemukan, diputuskan, diperhatikan, dipelajari dan disimpulkan. 
Tabel 1. Standar Berpikir Kritis yang Digunakan dalam Penelitian

\begin{tabular}{|c|c|c|}
\hline No. & Standart Berpikir Kritis & Indikator Berpikir Kritis \\
\hline 1 & Focus (fokus) & $\begin{array}{l}\text { a. Siswa dapat menuliskan hal yang diketahui dan hal } \\
\text { yang ditanya pada soal } \\
\text { b. Siswa dapat menuliskan operasi yang digunakan } \\
\text { dalam menyelesaikan soal }\end{array}$ \\
\hline 2 & Reason (alasan) & $\begin{array}{l}\text { a. Siswa mencari cara untuk menyelesaikan masalah } \\
\text { dengan memberikan alasan berdasarkan fakta atau } \\
\text { bukti yang relevan dari setiap langkah dalam } \\
\text { pembuatan keputusan } \\
\text { b. Siswa mampu mengerjakan soal sesuai dengan cara } \\
\text { yang telah direncanakan dengan mengungkapkan } \\
\text { alasan yang jelas. }\end{array}$ \\
\hline 3 & Inference (menyimpulkan) & $\begin{array}{l}\text { Siswa mampu membuat kesimpulan dari alasan yang } \\
\text { telah dikemukakan dengan benar. }\end{array}$ \\
\hline 4 & Situation (situasi) & $\begin{array}{l}\text { Siswa mampu menggunakan semua informasi yang telah } \\
\text { disesuaikan dengan permasalahan }\end{array}$ \\
\hline 5 & Clarity (kejelasan) & Siswa mampu membedakan beberapa hal dengan jelas \\
\hline 6 & Overview (tinjauan ulang) & $\begin{array}{l}\text { a. Siswa meneliti kembali secara menyeluruh. } \\
\text { b. Siswa mampu menemukan alternatif lain untuk } \\
\text { menyelesaikan permasalahan tersebut. }\end{array}$ \\
\hline
\end{tabular}

Sumber data Wardani (2010:29)

\section{METODE PENELITIAN}

Penelitian ini merupakan penelitian deskriptif kualitatif. Dilakukan untuk mengidentifikasi kemampuan berpikir kritis siswa dalam memahami materi operasi bentuk akar. Penentuan daerah dalam penelitian ini dilakukan dengan metode purposive area yang dilaksanan di SMA Muhammadiyah 4 Songgon. Populasinya siswa kelas X IPA 2 di SMA Muhammadiyah 4 Songgon. Pada penelitian ini pemilihan kelas sampel dilakukan dengan menggunakan teknik purposive sampling dan yang terpilih kelas X IPA 2 terdiri dari 17 siswa.

Teknik pengumpulan data yang digunakan dalam penelitian ini adalah sebagai berikut :

1. Metode Tes

Metode tes digunakan untuk memperoleh data kemampuan siswa dalam belajar. Masing-masing siswa diharapkan mampu menjabarkan jawabannya dengan baik agar bisa ditelusuri proses berpikir kritisnya. Soal tes yang disajikan dalam bentuk uraian yang harus diselesaikan yang terdiri dari 3 
soal, yang mencakup standart berpikir kritis yang digunakan yaitu : focus (fokus), reason (alasan), inference (menyimpulkan). Hasil tes diambil 3 subyek penelitian dari masing-masing gender.

2. Metode Wawancara

Metode wawancara digunakan untuk menggali data yang diperlukan dengan melalui tatap muka dengan responden, yang dianggap dapat memberikan informasi terhadap data yang dibutuhkan dalam kegiatan penelitian (Dimyati, 2013:68). Pertanyaan-pertanyaan tersebut dapat berkembang sesuai keadaan yang dihadapi selama wawancara berlangsung untuk menggali informasi lebih mendalam dari subyek penelitian. Selama proses wawancara dilakukan perekamanan suara agar tidak ada data yang terlewatkan. Hasil rekaman selanjutnya ditranskrip untuk digunakan dalam menganalisis data. Tes wawancara dilakukan setelah siswa mengerjakan tes untuk menghindari siswa lupa pada strategi yang digunakan dalam menyelesaikan soal tes, dengan mengambil masing-masing 3 subyek berdasarkan gender.

3. Metode Dokumentasi

Metode dokumentasi merupakan metode pengumpulan data kualitatif sejumlah besar fakta dan data tersimpan dalam bahan yang berbentuk dokumentasi (Sujarweni, 2014:33). Dokumentasi digunakan untuk mengumpulkan data berupa rekaman kejadian dikelas yang dianggap penting atau menggambarkan suasana kelas, ketika efektifitas belajar berlangsung.

Teknik analisis data yang digunakan dalam penelitian ini adalah sebagai berikut :

1. Reduksi Data

Reduksi data meliputi penyelesaian data melalui deskripsi atau gambaran singkat dan pengelompokan data dilakukan ke dalam kualifikasi yang telah ditentukan. Penelitian ini hasil tes dan hasil wawancara dilakukan reduksi data sehingga diambil data yang pokok dan penting. Mereduksi data dapat mendiskusikan pada teman atau orang lain yang dipandang ahli. 
2. Penyajian Data

Penyajian data dilakukan dalam rangka mengoperasikan data yang merupakan kegiatan penyusunan informasi secara matematik dari reduksi data sehingga memudahkan membaca data.Pada penelitian ini setelah data direduksi, selanjutnya data dipilah-pilah sesuai dengan gender.

3. Triangulasi Data

Triangulasi data dilakukan untuk mengecek keabsahan data. Triangulasi data dilakukan dengan cara mencocokkan semua data yang diperoleh dari semua sumber yang telah diperoleh, yaitu hasil wawancara dan hasil tes belajar.

4. Penarikan Kesimpulan

Penarikan kesimpulan adalah pemberikan makna pada data yang diperoleh dari penyajian data. Penarikan kesimpulan dilakukan berdasarkan hasil dari semua data yang diperoleh.

\section{HASIL DAN PEMBAHASAN}

Penelitian ini dilaksaksanakan di SMA Muhammadiyah 4 Songgon dengan responden terdiri dari 17 siswa dari kelas X IPA 2. Pada proses ini peneliti menentukan responden berdasarkan tes kemampuan dasar matematika secara individu. Hasil tes kemampuan dasar matematika diperoleh tingkat kemampuan dengan 5 kriteria yaitu: baik sebanyak 5 siswa, cukup sebanyak 9 siswa, kurang sebanyak 2 siswa, dan sangat kurang sebanyak 1 siswa. Pada masing-masing kriteria ditentukan 3 responden laki- laki dan 3 responden perempuan sebagai subyek penelitian. Responden dalam penelitian ini adalah siswa kelas X IPA 2 SMA Muhammadiyah 4 Songgon.

Tabel 2. Data Hasil Tes Kemampuan Responden

\begin{tabular}{cccccc}
\hline \multirow{2}{*}{$\begin{array}{c}\text { No. } \\
\text { Responden }\end{array}$} & L/P & \multicolumn{3}{c}{ Nilai } & \multirow{2}{*}{ Jumlah } \\
\cline { 2 - 5 } & & Soal 1 & Soal 2 & Soal 3 & \\
\hline 1 & L & 27 & 20 & 15 & 62 \\
\hline 2 & L & 27 & 20 & 32 & 79 \\
\hline 3 & L & 27 & 21 & 11 & 59 \\
\hline
\end{tabular}

58 TRANSFORMASI - Jurnal Pendidikan Matematika \&Matematika Vol. 3 No. 1 Edisi Bulan Juni Tahun 2019 ISSN: 2549-1164 


\begin{tabular}{cccccc}
4 & $\mathrm{~L}$ & 22 & 21 & 28 & 71 \\
\hline 5 & $\mathrm{P}$ & 18 & 24 & 36 & 78 \\
\hline 6 & $\mathrm{P}$ & 11 & 23 & 34 & 68 \\
\hline 7 & $\mathrm{~L}$ & 4 & 18 & 22 & 44 \\
\hline 8 & $\mathrm{~L}$ & 25 & 28 & 32 & 85 \\
\hline 9 & $\mathrm{P}$ & 18 & 28 & 22 & 68 \\
\hline 10 & $\mathrm{P}$ & 19 & 28 & 34 & 81 \\
\hline 11 & $\mathrm{~L}$ & 16 & 3 & 6 & 25 \\
\hline 12 & $\mathrm{~L}$ & 25 & 19 & 27 & 71 \\
\hline 13 & $\mathrm{~L}$ & 25 & 28 & 26 & 79 \\
\hline 14 & $\mathrm{P}$ & 25 & 28 & 17 & 70 \\
\hline 15 & $\mathrm{~L}$ & 16 & 9 & 23 & 48 \\
\hline 16 & $\mathrm{~L}$ & 15 & 26 & 28 & 69 \\
\hline 17 & $\mathrm{~L}$ & 21 & 25 & 24 & 70 \\
\hline
\end{tabular}

Berdasarkan tabel diatas maka peneliti mengambil hasil tes nilai tertinggi perempuan yaitu responden 5 , responden 10 , dan responden 14 sedangkan nilai tertinggi laki-laki yaitu responden 2 , responden 8 , dan responden 13 . Responden tersebut akan dilakukan wawancara mendalam dan direkam untuk mengetahui bagaimana siswa dalam menjawab tes yang telah dikerjakan.

Adapun hasil analisis kemampuan berpikir kritis siswa dalam memecahkan masalah matematika disajikan dalam deskripsi berikut :

(1) P1

P1 (Responden 14) menunjukkan bahwa subyek mampu mengerjakan tahap awal, dengan mencari cara untuk menyelesaikan masalah dengan memberikan alasan berdasarkan fakta atau bukti yang relevan dari setiap langkah dalam pembuatan keputusan. Mampu menuliskan operasi yang digunakan dalam menyelesaikan soal (focus/fokus). Mampu mencari cara untuk menyelesaikan masalah dengan memberikan alasan berdasarkan fakta atau bukti yang relevan dari setiap langkah dalam pembuatan keputusan 
(reason/alasan). dan mmpu membuat kesimpulan dari alasan yang telah dikemukakan dengan benar (inference/menyimpulkan).

\section{(2) P2}

P2 (Responden 5) menunjukkan bahwa subyek mampu mengerjakan tes soal mampu memahami dan menuliskan semua informasi yang diketahui atau ditanya (focus/fokus). Subyek mampu mencari cara untuk menyelesaikan masalah dengan memberikan alasan berdasarkan fakta atau bukti yang relevan dari setiap langkah dalam pembuatan keputusan (reason/alasan). Serta mampu menuliskan kesimpulan pada lembar jawaban dan mampu menjelaskan kesimpulan (inference/menyimpulkan).

\section{(3) P3}

P3 (Responden 10) menunjukkan bahwa subyek mampu menggunakan semua informasi yang sesuai dengan soal (situation/situasi).Subyek mampu membedakan hal yang diketahui dan hal yang ditanyakan pada soal (focus/fokus).seta mengetahui bahwa informasi pada soal sudah bisa menyelesaikan persoalan yang diberikan (clarity/kejelasan).

(4) L1

L1 (Responden 8) menunjukkan bahwa subyek mampu mengerjakan tes soal mampu memahami dan menuliskan semua informasi yang diketahui atau ditanya (focus/fokus). Subyek mampu mencari cara unuk menyelesaikan masalah dengan memberikan alsan berdasarkan fakta atau bukti yang relevan dari setiap langkah dalam pembuatan keputusan (reason/alasan). Subyek mampu menggunakan semua informasi yang sesuai dengan soal dan mampu mngetahui bahwa informasi pada soal sudah bisa menyelesaikan persoalan yang diberikan (clarity/kejelasan).

\section{(5) $\mathbf{L} 2$}

L2 (Responden 2) menunjukkan bahwa dalam mengerjakan tes soal mampu memahami dan menuliskan operasi yang digunakan semua informasi apa yang diketahui dan ditanyakan (focus/fokus). Subyek mampu mengerjakan soal sesuai dengan cara yang telah direncanakan dengan mengungkapkan alasan yang jelas (reason/alasan). Subyek meneliti kembali pengerjaannya, 
dengan cara mengoreksi pekerjaannya dari awal jika ada yang salah hitung (overview/tinjauan ulang).

\section{(6) $\mathbf{L 3}$}

L3 (Responden 13) menunukkan bahwa subyek mampu mengerjakan tes soal dan menuuliskan hal yang diketahui dan ditanyakan (focus/fokus).Subyek mampu mengerjakan tahap awal dalam menyelesaikan soal, dipertengahan menyelesaikan soal subyek mengalami kebinggungan dan tidak dapat menyelesaiakn soal tersebut (reason/alasan).

\section{KESIMPULAN DAN SARAN}

Berdasarkan hasil analisis dan pembahasan, kesimpulan dari penelitian ini adalah sebagai berikut :

1. Siswa perempuan kelas X IPA 2 SMA Muhammadiyah 4 Songgon memiliki kemampuan berpikir kritis yang sama. Mereka dapat memahami maksud soal dengan baik, dapat menuliskan hal yang diketahui dan hal yang ditanyakan dalam menyelesaikan soal. Siswa perempuan mampu mencari cara untuk menyelesaikan masalah dengan memberikan alasan yang jelas pada setiap langkah dalam menyelesaikan soal, cenderung mampu mengerjakan soal sesuai dengan cara yang telah direncanakan sebelumnya. Mereka mampu membuat kesimpulan dari semua permasalahan yang diberikan. Dalam menyelesaikan masalah siswa perempuan mampu menggunakan semua informasi yang ada pada soal dan mampu untuk menjawab pertanyaan. Siswa perempuan mampu meneliti kembali jawabannya yang telah dikerjakan secara menyeluruh dari awal hingga akhir, namun mereka tidak dapat menemukan alternatif lain untuk menyelesaikan soal yang diberikan. Siswa perempuan mampu memenuhi standart berpikir kritis yaitu focus, reason, inference, situasi dan clarity.

2. Siswa laki-laki kelas X IPA 2 SMA Muhammadiyah 4 Songgon mampu menuliskan langkah yang digunakan, namun pada saat wawancara siswa laki-laki mampu menjawab dengan baik. Hal ini mungkin dikarenakan siswa laki-laki lebih terburu-buru dalam mengerjakan soal. Sehingga tidak ada 
tahapan pada lembar jawab yang terlewatkan. Siswa laki-laki mampu mengerjakan dengan baik dan benar, namun pekerjaannya tidak sesuai dengan langkah penyelesaian yang sudah dipilih sebelumnya. Pada lembar tes siswa laki-laki menuliskan jawaban yang kurang benar, namun padsa saat wawancara dapat menjelaskan dengan runtut dan benar. Siswa laki-laki dapat mengetahui jawaban yang salah yang telah dikerjakan. Semua siswa laki-laki cenderungmeneliti kembali hasil pengerjaannya, namun tdak dapat memiliki alternatif penyelesaian lain untuk menyelesaikan permasalahan yang diberikan. Sehingga tidak memenuhi standart berpikir kritis serta dapat membedakan hal yang dibeberapa hal dengan jelas, sehingga siswa laki-laki dapat dikatakan cenderung memenuhi 4 standart berpikir kritis yaitu focus, reason, clarity, overview.

Berdasarkan penelitian yang telah dilakukan mengenai proses berpikir kritis siswa dalam menyelesaikan soal matematika berdasarkan gender, berupa saran yang dapat diberikan peneliti sebagai berikut :

1. Kepada guru, hendaknya membiasakan siswa dengan memberikan soal-soal dari tingkatan yang mudah hinggal yang sulit dan soal-soal yang dapat mengembangkan kemampuan berpikir kritis siswa. Membiasakan siswa mengerjakan soal tahap demi tahap agar meningkatkan ketelitian siswa.

2. Kepada siswa, hendaknya membiasakan membaca soal lebih dari sekali agar dapat memahami maksud soal, menyelesaikan soal tahap demi tahap dan lebih teliti dalam menyelesaikan soal sehingga mengurangi kesalahan dalam penyelesaian soal.

3. Kepada peneliti lain, hendaknya mencari literatur sebanyak-banyaknya untuk memperkuat teori. Subyek yang diambil untuk peneltian lebih banyak lagi akar hasil penelitian maksimal.

\section{REFERENSI}

Dimyati, J. (2013). Metodologi Penelitian Pendidikan dan Aplikasinya.Jakarta: Kencana Prenata Media Grup .

Ennis, R. (2009). Crytical Thinking. New Jersey: Prentice Hall. 
Julita.(2018). Peningkatan Kemampuan Pemecahan dan Hasil Belajar Matematika Melalui Problem Based-Learning.Jurnal Mosharafa,Volume 7, , 144.

Kafiar, E., \& Kho, R. (2015).Proses Berfikir Siswa SMA Dalam Memecahkan Masalah Matematika Pada Materi SPLTV dari Gaya Kognitif Field Independent Dan Field Dependent.Jurnal Ilmiah Matematika dan Pembelajarannya Volume 1 Nomor 2 , 40.

Sujarweni, V. W. (2014). Metodelogi Penelitian .Yogyakarta: Pusaka Baru Press. Wardani, S. (2010). Mengembangkan Kemampuan Pemecahan Masalah, Kreativitas Matematik dan Kemandirian Belajar Siswa Melalui Pembelajaran Multimedia Interaktif . Seminar Pendidikan Matematika (hal. 29). Tasikmalaya : Universitas Siliwangi Tasikmalaya . 